\title{
The Challenges and Policy Support for High- Conservation Area Management in Indonesia
}

\author{
Galih Kartika Sari ${ }^{1}$, Fitri Nurfatriani ${ }^{1}$, Ramawati $^{1}$, Heru Komaruddin ${ }^{2}$ \\ \{galihkartika@gmail.com; nurfatriani@yahoo.com; rymai_taurus@yahoo.com; \\ h.komarudin@cgiar.org\} \\ ${ }^{1}$ Research and Development Center of Social, Economic, Policy, and Climate Change - Ministry of \\ Environment and Forestry Indonesia \\ ${ }^{2}$ Centre for International Forestry Research
}

\begin{abstract}
The pressures to protect the forest in a forest and non-forest areas has been increased recently. Even though, the stakeholders as the government and private sector have positive responses by taking initiatives, such as setting conservation areas with high-conservation value (HCV) in non-state forest areas. The HCV management faces challenges as the lack of a regulatory framework to protect forests in non-state forest areas, disharmony on land use regulations for $\mathrm{HCV}$ in plantations areas, disharmony between voluntary market-based mechanisms standard and existing regulations. Further, HCV management is compounded by a lack of forested land conservation awareness among stakeholders and incentive policies that promote HCV areas management. The study aims to assess national and sub-national policies, the regulatory frameworks, and examine challenges to implement HCV management effectively. The research was conducted in Kotawaringin Timur (Central Kalimantan) and Landak (West Kalimantan) district. The study applied several analyses, such as gap policy analysis, fiscal analysis, and institutional analysis. The research results recommend that several incentive policies and regulations be strengthened and harmonized. Furthermore, it is necessary to design fiscal incentives for HCV area managers to receive land and buildings tax deduction. Moreover, an incentive scheme and institutional incentive are needed to reward actors with good HCV management performance.
\end{abstract}

Keywords: Biodiversity, HCV Management, Incentive Policies, Palm Oil 


\section{Introduction}

Forest management in Indonesia regulated in-laws and regulations that divides forest areas according to their functions and purposes, consisting of conservation forests, protected forests, and production forests. Biodiversity protection has thus focused in conservation forests and protected areas, which are generally located in the highlands, while the field realities indicate that biodiversity found outside conservation areas [1], which are under serious threat. A study found that around $80 \%$ of endangered wildlife found to be outside the conservation area and around $75 \%$ of the wild Orang Utan live outside the conservation area [2]. Thus, it takes efforts to protect biodiversity and essential ecosystems outside conservation areas, which would maintain connectivity and habitat that are essential for the survival of species across fragmented agriculture or plantations landscapes.

The high demand for land is a consequence of the massive development in developing countries, particularly for the production area. Agriculture and plantation sectors require a large extent of lands and become the second-largest land use and cover after forest cover of the total land area of Indonesia [3]. The forest cover change both in the forest area and outside the forest area is unavoidable to meet land needs that have an impact on reducing biodiversity [4]. One of the activities that become the particular concern of the public and is considered a cause of biodiversity loss is the development of oil palm [5].

As the response to the negative issues that addressed to the palm oil sector, public and private sectors took some measures to improve the management of oil palm plantations and to ensure sustainable products along the supply chain by devising policies and mandatory rules and by complying with voluntary certification systems. The efforts made by the Ministry of Environment and Forestry one of them through the formulation of a Ministerial regulation on the determination of essential ecosystem areas (KEE) aimed to protect areas that ecologically support the sustainability of life through biodiversity conservation efforts for community welfare which designated as protected areas. [6,7]. Among voluntary certification systems, growers committed to sustainable palm oil are required to protect areas of high conservation value (HCV) and biodiversity within their concession units by making an assessment of $\mathrm{HCV}$ and taking necessary management plans [8]. 
The term of HCV was first introduced by the Forest Stewardship Council (FSC) in the forestry sector in 1999, which is part of the principles in the FSC standard that must be fulfilled by the certification scheme for sustainable natural forest management. However, the HCV concept applied in various uses, one of which is the certification of sustainable oil palm plantations adopted by the Roundtable on Sustainable Palm Oil (RSPO) which is still voluntary $[9,10]$. The Indonesian government is also implementing a certification system for sustainable oil palm plantations known as Indonesian Sustainable Palm Oil (ISPO) to improve the competitiveness of Indonesian palm oil at the global level [11].

Nevertheless, HCV development in oil palm plantations still faces some challenges. HCV development is still considered a cost by business actors and unclear the regulation that governs HCV areas. On the other hand, The global oil palm market demand continues to emphasize the guarantee of sustainable management of oil palm that can be demonstrated by the implementation of a certification system and the development of HCVs that are part of the principle of certification of oil palm plantation. The unavailability of a precise regulation is a challenge in developing $\mathrm{HCV}$ because it opens opportunities for the conversion of high forest cover in plantation areas that are supported by regulations and choices to be rational due to economic considerations versus conservation considerations. $\mathrm{HCV}$ area is part of KEE, might cover areas of production forest, watershed protection forest and non-state forest (APL), The KEE classified into four categories namely wetland ecosystem, biodiversity park, wildlife corridor, and high conservation value, $[2,6]$. Nonetheless, recent studies have shown that for those voluntary mechanisms, Indonesia's were unprepared institutionally and policy [12].

Therefore, this paper aims to assess various national as well as subnational policies and regulatory framework and to examine challenges that impede the effective management of $\mathrm{HCV}$ areas.

\section{Methodology}

\subsection{Research Framework}


Protecting forested areas outside the conservation areas, especially in production zones, is a challenge in natural resources management. Options for converting forested areas to non-forestry use become rational choices when those areas are outside conservation areas and within the production zone. Multi-stakeholder initiatives, especially large companies that committed to maintaining the high forest cover area through no deforestation or zerodeforestation pledges considered not yet sufficient to mobilize all related elements, especially the private sector in $\mathrm{HCV}$ management. Although currently, market demand has required sustainable production using certification instruments such as RSPO. The scope of the paper is to discuss the challenges and constraints as well as incentive policies that expected to encourage the management and protection of $\mathrm{HCV}$ areas in oil palm plantations.

Gap policy analysis was conducted to analyze policies related to $\mathrm{HCV}$ management in Indonesia. In Indonesia's conservation policies, HCV areas located outside conservation areas, especially in oil palm plantations, these are part of the Essential Ecosystem Area (EEA). At present, there is the absence of a formal legal basis governing the management of this EEA area. At the same time, the threat of converting forest cover to oil palm plantations is still high. Therefore a supporting policy is needed as an incentive for HCV area managers to maintain their forested areas. This study conducted a fiscal analysis as well to assess incentive policies that support sustainable palm oil management implementation. The research focuses on government revenues derived from taxes, non-tax, and user fees, including government spending related to oil palm management. This paper refers to incentive policy theory as the basic theory, which is expected to be a policy that can change people's motivation and behavior. Enters [13] stated that incentive policy is inducement and incitement of an action. In comparison based on Giger [14], incentive policies can motivate or or stimulate people to act. In other words, incentive policies can encourage people and business entities' behavioral change to develop sustainable palm oil management through management and protection of the $\mathrm{HCV}$ area.

Based on the incentive theory policy as stated above, some challenges in managing $\mathrm{HCV}$ areas in oil palm plantations are expected to be overcome by a series of incentive policies to be formulated. As a support to the incentive theory policy, the study used institutional analysis to determine the relationship between HCV management institutions in Indonesia. For this reason, this paper uses a qualitative approach to analyze the regulatory framework for management and protection of $\mathrm{HCV}$ areas, challenges, and obstacles in the management and protection of $\mathrm{HCV}$ areas in oil palm plantations and incentive 
policies that are expected to encourage the management and protection of $\mathrm{HCV}$ areas.

\subsection{Data collection and analysis}

Data collection accomplished by conducting in-depth interviews with 101 key informants from various stakeholders: the government, oil palm companies, associations, academics and CSOs; through focus group discussions (FGD) and literature studies. Respondents in this study are parties related to the national palm oil industry and are interested in the development of the national palm oil industry. Further, the selection of respondents was conducted by purposive sampling method, which was carried out by determining the specific characteristics of the respondents by the research objectives so that they were expected to answer the research problems. The data collection and research process took place in 2017. The research locations were in Kotawaringin Timur District, Central Kalimantan and Landak District in West Kalimantan as well as in Jakarta.

Important questions that will answer from this paper are:

1) What is the regulatory framework for the management and protection of $\mathrm{HCV}$ areas?

2) What are the challenges faced in managing and protecting HCV areas?

3) What incentive policies expected to encourage the parties to strengthen the management and protection of $\mathrm{HCV}$ areas?

Gap policy analysis, fiscal analysis, and institutional analysis was conducted to answer those research questions above as described in the Table 1.

Table 1. Theory, method of data analysis, variables and data source

\begin{tabular}{|c|c|c|c|c|}
\hline Objective & The Theory & $\begin{array}{l}\text { Method/Data } \\
\text { Analysis }\end{array}$ & Variable & $\begin{array}{c}\text { Data } \\
\text { Resources }\end{array}$ \\
\hline $\begin{array}{l}\text { 1. To assess } \\
\text { various national } \\
\text { as well as } \\
\text { subnational } \\
\text { policies and } \\
\text { regulatory } \\
\text { framework of } \\
\text { HCV area } \\
\text { management } \\
\text { and protection }\end{array}$ & $\begin{array}{l}\text { Incentive policy } \\
\text { theory } \\
\text { 1999) }\end{array}$ & $\begin{array}{l}\text { 1. Gap policy analysis } \\
\text { 2. Policy instrument } \\
\text { analysis (Krott, } \\
\text { 2005) } \\
\text { a. Regulation } \\
\text { instrument } \\
\text { analysis } \\
\text { b. Fiscal } \\
\text { Instrument } \\
\text { analysis } \\
\text { 3. Institutional analysis }\end{array}$ & 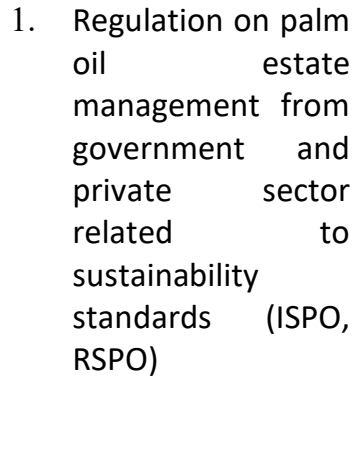 & $\begin{array}{l}\quad \text { CPO Fund } \\
\text { Management } \\
\text { Agency, } \\
\text { Ministry of } \\
\text { Agriculture, } \\
\text { Ministry of } \\
\text { Environment } \\
\text { and Forestry, } \\
\text { Coordinator } \\
\text { Ministry of } \\
\text { Economic, }\end{array}$ \\
\hline
\end{tabular}




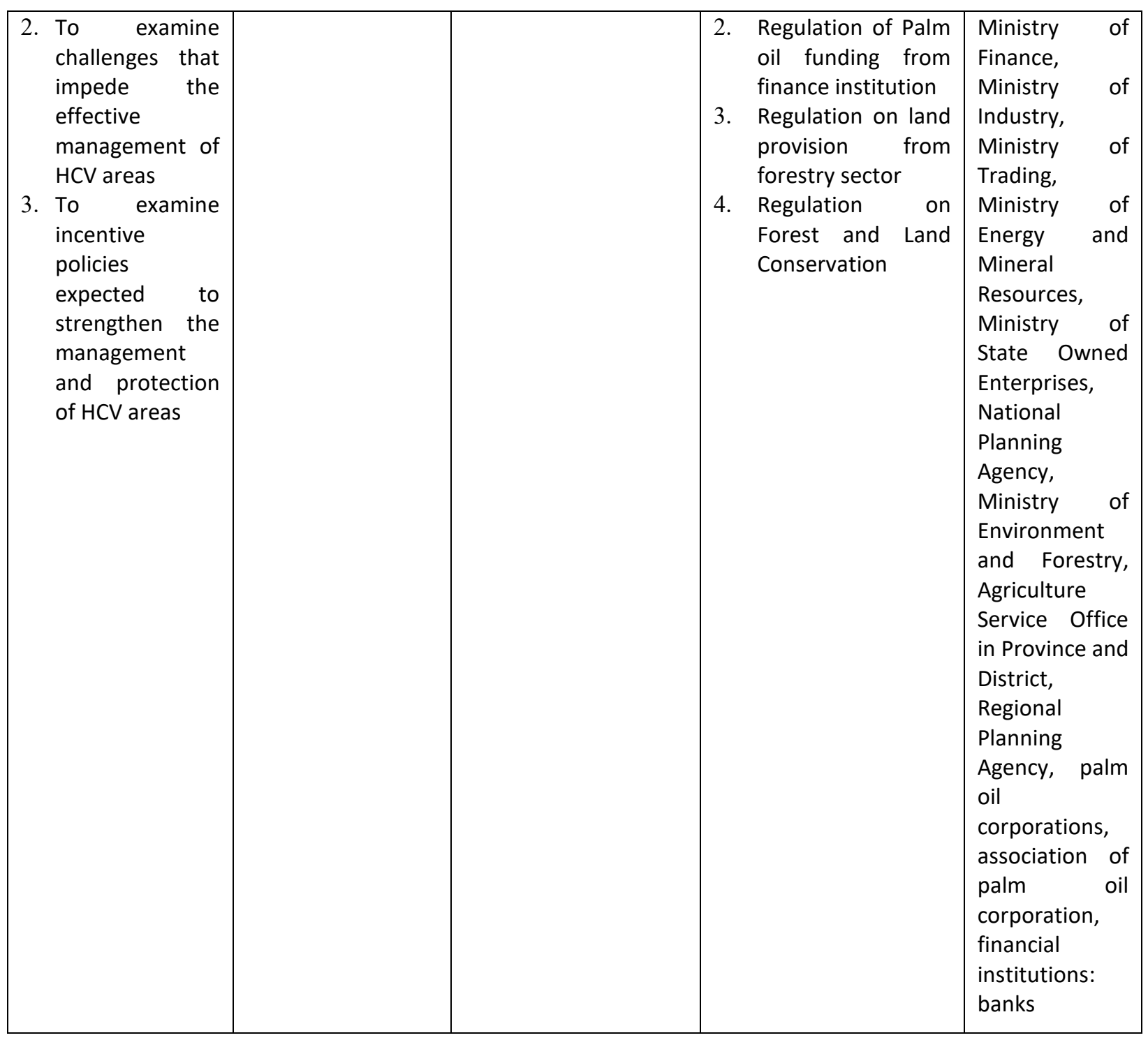

\subsubsection{Gap policy analysis}

Gap analysis is used to identify the gaps of fiscal and regulatory instruments related to $\mathrm{HCV}$ areas management and protection in palm oil plantation through examining the conformity of policies and legislation with its implementation (Nurfatriani et al., 2015). This study will use this approaches to provide the picture of the current situation of the HCV areas management and protection in palm oil plantation, and the design of incentive policies that supports the $\mathrm{HCV}$ areas management and protection. Gap analysis also serves to determine the difference between the current actual conditions with the desired conditions in 
the future, through the identification of current gaps in infrastructure planned to be achieved [15].

\subsubsection{Fiscal analysis}

Fiscal approach is used to describe the revenue earned and used to generate achievements [15]. Fiscal analysis is conducted to assess incentive policies that support HCV areas management and protection in palm oil plantation. The research focuses on government revenues derived from taxes, non-tax, and user fees, including government spending related to oil palm management and $\mathrm{HCV}$ area management and protection.

\subsubsection{Institutional analysis}

Thomas et al, 1978 [16] defined Institutions are "manifestations of a society's normative formulations; they embody society's judgments about the desirability of actions, events, and products". Meanwhile, Ostrom [17] defined institutional analysis as "the examination of how rules, goods and production technologies, and communities of understanding jointly affect the structure of situations in which individuals face incentives, adopt strategies of actions, and produce outcomes for themselves and others". Based on those definition, institutional analysis is used to analyze the rules of game un the form of relevant regulations related to $\mathrm{HCV}$ areas management and protection in palm oil plantation, as well as to examine the relationship between HCV management institutions in Indonesia 


\section{HCV Management in Indonesia}

The HCV approach was first developed by the Forest Stewardship Council (FSC) and was adopted in 1999. Nowadays it is used by a range of certification schemes, including the Roundtable on Sustainable Palm Oil (RSPO) and the Round Table on Responsible Soy (RTRS), and has been applied globally in tropical, temperate and boreal regions [18]. The approach is therefore not only in forest sector but also in palm oil and other commodity sectors. While RSPO has adopted HCV, it has not been explicitly used as a common standard to mitigate hostile environment and social impacts in Indonesia's mandatory system for sustainable palm oil or ISPO. There have been initiatives by some local governments across the country to adopt HCV in their local regulations to ensure sustainable plantations, and that happened long before the Ministry of Environment and Forestry embarked recently on a policy referred to as essential ecosystem area or Kawasan Ekosistem Esensial.

The impetus for the protection of HCVs in the oil palm sector came from various initiatives and actors. Along with HCS or High Carbon Stock, HCV is considered a sustainability approach to maintaining or enhancing the environment and social values in oil palm production landscapes. The approach has been an essential part of the private sector initiatives to address issues around biodiversity loss, damaged environmental services and labour or community exploitation. If we refer to a typology developed by [15], there are various initiatives or group of actors involved to protect biodiversity and habitat loss and avoid destructive impacts on local people. They include collective aspirations, company pledges, codes of conduct and sectoral standards, where $\mathrm{HCV}$ has been highlighted as one vital instrument to help actor's measure toward realizing sustainability. 
The collective aspirations, such as Consumer Goods Forums, One Planet Business for Biodiversity (OP2B), Palm Oil Innovation Group (POIG), Forum for Sustainable Palm Oil (FONAP) and FOKSBI or Indonesian Platform for Sustainable Palm Oil, have the requirement of the raw material for the members. These requirements include: the raw material sources have come from plantations and farms whose have an operation that complies with laws and regulations and meets the voluntary standards including RSPO principles and criteria, protecting high conservation value (HCV) areas, respecting human rights and engaging in free prior and informed consent of indigenous and local communities. Some of the groups aim to eliminate deforestation, enhance the management, restoration and protection of high-value natural ecosystems. Their members are required to agree on specific actions to protect and restore the world's most biodiversity-rich and fragile ecosystems, including grasslands, wetlands and forests.

As part of the environmental responsibility requirement, oil palm company who are members of POIG are committed to de-linking the production of palm oil from deforestation by undertaking HCV assessments and obtaining Free, Prior and Informed Consent (FPIC) to use land. In order to protect and conserve the rare, and threatened or endangered species, the concessionaires shall undertake comprehensive biodiversity surveys to identify HCV 1-3 and make a positive contribution to the survival of those species in areas beyond the concession. Management plans, including actions for the protection of wildlife species within and beyond concession, shall be in place.

$\mathrm{HCV}$ instruments are included in the criteria and indicators of voluntary certification standards for palm oil such as RSPO and ISCC or International Sustainability and Carbon Certification, to which most of the Indonesian companies must comply with before they are certified sustainable. Companies voluntarily set aside areas within their concessions for community livelihoods and conservation. In order to conserve, protect and enhance ecosystems that provide for the next generation, RSPO standard requires that companies follow criteria stating that land clearing does not cause deforestation or damage any area required to protect or enhance HCVs or HCS. HCVs and HCS forests in the managed area are identified and protected or enhanced $[3,16]$. RSPO criteria also stated that land clearing since Nov 2005 had not damaged primary forest or any area required to protect or enhance HCVs. By 15 November 2018, HCVs, HCS forests, peatland and other conservation areas that were identified within the palm oil plantations, they are protected and/or enhanced. An integrated management plan to protect and/or enhance HCVs, HCS forests, peatland and other conservation areas developed, implemented and adapted where necessary. 
RSPO criteria also set out that where there has been landed clearing without prior HCV assessment since November 2005, or without prior HCV-HCSA assessment since 15 November 2018, the Remediation and Compensation Procedure $(\mathrm{RaCP})$ applies.

The company shall have HCV management and monitoring plans (developed in collaboration with stakeholders) at a landscape level. Such collaborative plans and areas shall include but are not limited to: management of corridors, buffer zones, anti-poaching and encroachment activities, watercourses and wetlands, including riparian zone management, steep slope management and livelihoods and cultural identity.

As of 31 August 2019, a total area of 3.97 million hectares have been certified under this system, with a total volume of 14.8 million tonnes accounting for $19 \%$ of global palm oil. Indonesia accounts for about $51.5 \%$ of the total area certified and $55.4 \%$ of the total volume of RSPO certified sustainable palm oil.

Similarly, ISCC requires the growers committed to sustainability and pursue this certification to adhere to one principle aimed to protect lands with high biodiversity value or high carbon stock. The objective is to protect areas which are bio diverse or rich in carbon, which serve the protection of threatened or vulnerable species, or which have other ecological or cultural importance. High conservation value (HCV) areas shall be protected.

The importance of protecting biodiversity, habitat and ecosystems and respect human rights and empower local communities, and need to adopt HCV have also been highlighted in sustainability policies issued by leading oil palm company groups and companies. The policies are called under a various title such as No Deforestation, No Peat, No Exploitation, or NDPE (2013) and conservation policy, Forest Conservation Policy, etc.

\section{Regulatory Framework Of HCV Management In Indonesia}

The palm oil sectors have a contribution to the preservation of biodiversity and its ecosystem through The High Conservation Value (HCV) management within the concession area. In addition, the sustainability issue in palm oil international market demands plays a crucial role in the development of $\mathrm{HCV}$ management areas in Indonesia. The issue of sustainability is accommodated as a certification system such as RSPO. The RSPO certification system has an important part in the adoption of $\mathrm{HCV}$ in the exploitation of oil palm plantations in Indonesia [16]. 
The development of HCV management is a part of the policy framework in Indonesia. The policies are cross-sectoral policy and engaged multistakeholders. Those can be seen in the table 1, while the detail of the regulation's content and the regulation gap is written in the appendix 1 .

Table 2. Regulatory Framework of Protection and Management of HCV in Indonesia's Oil Palm Plantation

\begin{tabular}{|c|c|c|c|c|}
\hline No & Regulations & Content & Implementation & Gap \\
\hline 1 & $\begin{array}{l}\text { The Law No. } 5 \text { of } 1990 \\
\text { on Conservation of } \\
\text { Biological Resources and } \\
\text { Their Ecosystems }\end{array}$ & $\begin{array}{l}\text { The implementation of } \\
\text { biodiversity and ecosystem } \\
\text { conservation can be hand } \\
\text { over to the local } \\
\text { government in some affairs. }\end{array}$ & $\begin{array}{l}\text { implemented only in the } \\
\text { management of forest } \\
\text { park (Tahura). }\end{array}$ & $\begin{array}{l}\text { - Essential ecosystems } \\
\text { conservation, HCVF and } \\
\text { wildlife corridors in non- } \\
\text { conservation and state forest } \\
\text { area have not been } \\
\text { accommodated [17] } \\
\text { - The absence of regulations } \\
\text { related to the concurrent } \\
\text { division of government affairs } \\
\text { between the central, } \\
\text { provincial, and regional } \\
\text { governments to the } \\
\text { preservation of natural } \\
\text { resources and its ecosystems } \\
{[22] .}\end{array}$ \\
\hline 2 & $\begin{array}{l}\text { The Law No. } 32 \text { of } 2009 \\
\text { on Environmental } \\
\text { Protection and } \\
\text { Management }\end{array}$ & $\begin{array}{l}\text { The establishment and } \\
\text { implementation of } \\
\text { environmental economic } \\
\text { instruments by the } \\
\text { government to preserve } \\
\text { environmental functions. } \\
\text { These instruments include } \\
\text { a)The development and } \\
\text { economic planning } \\
\text { activities; b) environmental } \\
\text { funding and c)incentives } \\
\text { and/or disincentives. }\end{array}$ & $\begin{array}{l}\text { The establishment of the } \\
\text { Environmental Funding } \\
\text { Agency under the } \\
\text { Ministry of Finance. The } \\
\text { agency aims to manage } \\
\text { financing in the } \\
\text { environment sector }\end{array}$ & \\
\hline 3 & $\begin{array}{l}\text { The Law no } 39 \text { of } 2015 \\
\text { on Plantations }\end{array}$ & $\begin{array}{l}\text { Article } 16 \\
\text { (1). The company shall } \\
\text { endeavor Land Plantation } \\
\text { a. No later than three (3) } \\
\text { years after granting the } \\
\text { status of land rights, the } \\
\text { company shall endeavor } \\
\text { Plantation land at least } 30 \%\end{array}$ & $\begin{array}{l}\text { The Monitoring and } \\
\text { evaluation of plantation } \\
\text { conducted by the district } \\
\text { government or the } \\
\text { licensor }\end{array}$ & $\begin{array}{l}\text { The companies that allocate } \\
\text { their concession areas for HCV } \\
\text { threatened with revocation of } \\
\text { the license }\end{array}$ \\
\hline
\end{tabular}




\begin{tabular}{|c|c|c|c|c|}
\hline & & $\begin{array}{l}\text { of the area of land rights; } \\
\text { and } \\
\text { b. No later than } 6 \text { years after } \\
\text { granting the status of land } \\
\text { right, the company shall } \\
\text { seek the whole vast } \\
\text { plantation land rights which } \\
\text { technically can be planted } \\
\text { plantation } \\
\text { (2). If the land is not } \\
\text { cultivated plantation in } \\
\text { accordance with the } \\
\text { provisions referred to in } \\
\text { paragraph (1), a field that } \\
\text { has not been cultivated } \\
\text { plantation land was taken } \\
\text { over by the state in } \\
\text { accordance with the } \\
\text { provision of the legislation }\end{array}$ & & \\
\hline 4 & $\begin{array}{l}\text { The Law No. } 23 \text { of } 2014 \\
\text { concerning Regional } \\
\text { Government }\end{array}$ & $\begin{array}{l}\text { - Classifying government } \\
\text { affairs into } 3 \text { function, as } \\
\text { absolute government } \\
\text { affairs, concurrent } \\
\text { government affairs and } \\
\text { general government } \\
\text { affairs; } \\
\text { - Forestry is included in } \\
\text { concurrent affairs and } \\
\text { selected governmental } \\
\text { affairs }\end{array}$ & $\begin{array}{l}\text { - The Forest park } \\
\text { management is } \\
\text { implemented by } \\
\text { provincial/district/city } \\
\text { governments } \\
\text { - The local government } \\
\text { has an authority in the } \\
\text { plantation sector } \\
\text { - There is a district } \\
\text { government that } \\
\text { regulates licensing on } \\
\text { plantations by } \\
\text { requiring HCV } \\
\text { management in } \\
\text { plantations } \\
\text { concession. }\end{array}$ & $\begin{array}{l}\text { The absence of the institutions } \\
\text { that supervise local } \\
\text { governments that are committed } \\
\text { to implementing conservation } \\
\text { activities in plantation } \\
\text { concession areas }\end{array}$ \\
\hline 5 & $\begin{array}{l}\text { Presidential Decree No } \\
32 \text { of } 1990 \text { on } \\
\text { Management of Protected } \\
\text { Areas }\end{array}$ & $\begin{array}{l}\text { The Presidential } \\
\text { Regulation aims to } \\
\text { prevent damage to the } \\
\text { environmental sector. } \\
\text { The goal is to manage the } \\
\text { protection of nature, } \\
\text { climate, plants, animals, } \\
\text { and the cultural heritage } \\
\text { as well as the historical } \\
\text { and cultural values of the } \\
\text { nation. }\end{array}$ & $\begin{array}{l}\text { As the reference for } \\
\text { the plantation sector } \\
\text { businesses to identify } \\
\text { and protect areas of } \\
\text { protected forest, peat } \\
\text { land, water absorption } \\
\text { areas, and coastal } \\
\text { border river or the } \\
\text { area around the } \\
\text { lake/reservoir, or } \\
\text { springs[16] }\end{array}$ & \\
\hline
\end{tabular}




\begin{tabular}{|c|c|c|c|c|}
\hline & & $\begin{array}{l}\text { - The protected area } \\
\text { includes: } \\
\text { 1. } \begin{array}{l}\text { Areas that protect } \\
\text { the downstream } \\
\text { area }\end{array} \\
\text { 2. } \begin{array}{l}\text { Local protected } \\
\text { area }\end{array} \\
\text { 3. } \begin{array}{l}\text { The nature } \\
\text { reserve and } \\
\text { cultural heritage } \\
\text { area }\end{array} \\
\text { 4. Areas prone to } \\
\text { natural disasters }\end{array}$ & & \\
\hline 6 & $\begin{array}{l}\text { Director General of } \\
\text { Conservation on Natural } \\
\text { Resources and } \\
\text { Ecosystems Decree No. } \\
\text { P.5 / KSDAE / SET / } \\
\text { KUM.1 / 9/2017 } \\
\text { concerning Technical } \\
\text { Guidelines for } \\
\text { Determining High } \\
\text { Conservation Value } \\
\text { Areas Outside the Nature } \\
\text { Reserve Area, Nature } \\
\text { Conservation Area and } \\
\text { Hunting Park }\end{array}$ & $\begin{array}{l}\text { Technical guidance to } \\
\text { determine the High } \\
\text { Conservation Value (HCV) } \\
\text { area in the non-nature } \\
\text { conservation area and } \\
\text { hunting park }\end{array}$ & $\begin{array}{l}\text { Used to identify the high } \\
\text { conservation value areas } \\
\text { that are on the non-nature } \\
\text { conservation area and } \\
\text { Hunting Park }\end{array}$ & \\
\hline 7 & $\begin{array}{l}\text { The Minister of Agrarian } \\
\text { affairs and spatial } \\
\text { planning/Head of } \\
\text { National Land Agency } \\
\text { circular letter : No. } \\
\text { 10/SE/VII/2015 } \\
\text { concerning issuance of } \\
\text { permits in high } \\
\text { conservation value forest } \\
\text { areas on } 7 \text { July } 2015\end{array}$ & $\begin{array}{l}\text { The circular letter to protect } \\
\text { High Conservation Value } \\
\text { Forests in Plantation areas } \\
\text { originating from the release } \\
\text { of forest areas. }\end{array}$ & $\begin{array}{l}\text { In general, HCV managers } \\
\text { in plantation concessions } \\
\text { are certified plantations, } \\
\text { especially RSPO. }\end{array}$ & $\begin{array}{l}\text { The absence of an } \\
\text { institution/agency that is } \\
\text { responsible for ensuring the } \\
\text { plantation companies that } \\
\text { originate from the release of } \\
\text { forest areas have to protect } \\
\text { High-Value Conservation } \\
\text { Forest (HCVF). }\end{array}$ \\
\hline 8 & $\begin{array}{l}\text { Minister of Environment } \\
\text { and Forestry Regulation } \\
\text { No. } \\
\text { P.8/Menlhk/Setjen/OTL.0 } \\
/ 1 / 2016 \text { concerning The } \\
\text { Organization and Work } \\
\text { Procedure of the Natural } \\
\text { Resource Conservation }\end{array}$ & $\begin{array}{l}\text { Regulates the organization } \\
\text { and works procedures of the } \\
\text { technical implementation } \\
\text { unit for the conservation of } \\
\text { the natural resource.. }\end{array}$ & $\begin{array}{l}\text { The HCV manager will } \\
\text { coordinate with the } \\
\text { Natural Resources } \\
\text { Conservation Agency. } \\
\text { The Coordination conduct } \\
\text { if there are protected } \\
\text { wildlife in the HCV area. } \\
\text { Furthermore, the } \\
\text { plantation company as the }\end{array}$ & $\begin{array}{l}\text { The coordination only carried } \\
\text { out in the context of wildlife } \\
\text { and plants protection are not } \\
\text { include HCV management. }\end{array}$ \\
\hline
\end{tabular}




\begin{tabular}{|c|c|c|c|c|}
\hline & $\begin{array}{l}\text { Technical } \\
\text { Implementation Unit }\end{array}$ & & $\begin{array}{l}\text { managers of HCV sends a } \\
\text { report every three months } \\
\text { to the conservation unit } \\
\text { agency as mandated by the } \\
\text { Minister of Agriculture } \\
\text { regulation } 11 / 2015 \text { about } \\
\text { ISPO. }\end{array}$ & \\
\hline 9 & $\begin{array}{l}\text { Presidential Regulation } \\
\text { No. } 44 \text { of } 2020 \\
\text { concerning Indonesian } \\
\text { Sustainable Palm Oil } \\
\text { Plantation Certification } \\
\text { System }\end{array}$ & $\begin{array}{l}\text { Regulates ISPO } \\
\text { certification. In this } \\
\text { regulation ISPO } \\
\text { certification is required for } \\
\text { all plantation businesses, } \\
\text { both plantation companies } \\
\text { and/or smallholders }\end{array}$ & $\begin{array}{l}\text { Look forward to the policy } \\
\text { issuance as a derivative } \\
\text { from presidential } \\
\text { regulations. }\end{array}$ & \\
\hline 10 & $\begin{array}{l}\text { Ministry of Agriculture } \\
\text { Regulations No. } \\
\text { 11/Permentan/OT.140/3/ } \\
\text { 2015 concerning } \\
\text { Indonesian Sustainable } \\
\text { Palm Oil Certification } \\
\text { System/ISPO }\end{array}$ & $\begin{array}{l}\text { Establish guidelines for } \\
\text { Indonesia's sustainable } \\
\text { palm oil plantations }\end{array}$ & $\begin{array}{l}\text { The data shows that until } \\
\text { January } 2020 \text {, the total } \\
\text { area of ISPO certified } \\
\text { plantation covering an } \\
\text { area of } 5.45 \text { million ha. In } \\
\text { the area have been issued a } \\
621 \text { certificate that } \\
\text { consists of } 607 \text { companies, } \\
\text { ten smallholders } \\
\text { cooperative, and four } \\
\text { village units cooperatives } \\
\text { (KUD)plasma [18] }\end{array}$ & \\
\hline 11 & $\begin{array}{l}\text { Government Regulation } \\
\text { No. } 40 \text { of } 1996 \text { on } \\
\text { Business Right, Building } \\
\text { Right and Land Use } \\
\text { Right }\end{array}$ & $\begin{array}{l}\text { Article } 12 \\
\text { (1). b. Conducted an } \\
\text { agricultural, plantation, } \\
\text { fishery, and/or livestock } \\
\text { business following their } \\
\text { designation and } \\
\text { requirements as stipulated } \\
\text { in the decision to grant their } \\
\text { rights. }\end{array}$ & $\begin{array}{l}\text { The commodities planted } \\
\text { in the whole area of } \\
\text { concession }\end{array}$ & $\begin{array}{l}\text { There is no space for the } \mathrm{HCV} \\
\text { management }\end{array}$ \\
\hline
\end{tabular}

Even though HCV management inexplicitly mentions in Indonesia's legal framework, the law no. 5 of 1990 concerning Conservation of biodiversity and its ecosystem provides a space for protection and management of areas that have high biodiversity and are a buffer zone for the surrounding area. The protections are not only in the forest area but also in the non-forest area. Moreover, the central government regulations adjust the involvement of parties in the biodiversity and its ecosystem conservation. 
However, on the contrary, the agrarian law, Government Regulation No. 40 of 1996 on Business Right, Building Right, and Land Use Right were not allowed to allocate the concession area for HCV management. However, there is an exception for the business right area originating from the release of forest areas. As mentioned on the Minister of Agrarian Affairs and Spatial Planning/Head of National Land Agency Circular Letter: No.10/SE/VII/2015 on Issuance of Permits in High Conservation Value Forest Areas on 7 July 2015.

Specifically for the plantation sector, Law no. 23 of 2014 concerning Local Government states that licensing for the plantation sector is the authority of the district government. The regulation assigns the district government in a strategic position of the $\mathrm{HCV}$ protection in the plantation concession. The district government's commitments proved by the existence of local government regulations relating to and supporting conservation [16]. The regional regulations drawn up are driven by local government initiatives to protect biodiversity and their ecosystems. Initiatives for Conservation, for example, were shown by East Kutai District, which took initiatives to make the Wehea forest area a conservation forest area [19]. Additionally, the government of East Kutai Regency also has a regional regulation No. 6 of 2005 concerning plantation business permits in East Kutai Regency that regulates HCV protection in plantation HGUs. As stated in article 27, paragraph 1, letter c, "From each area based on the net area of the location permit issued, each plantation business actor required to provide an area of $10 \%$ for the conservation area".

In addition to the local government, $\mathrm{HCV}$ management initiatives can come from the private sector, indigenous peoples, and NGOs. The parties can collaborate in managing HCV. The Wehea Kelay Landscape Management is collaborative management between the government, community, the private sector, and NGOs. The Wehea-Kelay landscape is an Orang Utan corridor that has a 532,143 ha area. According to the Working Group of Wehea-Kelay Landscape Management [17], the stakeholders in the Wehea-Kelay landscape are the Wehea Protection Forest Management Agency, seven of IUPHHK-HA, two of IUPHHK-Plantation Forests, and six of oil palm companies. The parties incorporated in the Wehea-Kelay Essential Ecosystem Areas (KEE) forum supported by the regional government and the central government through the East Kalimantan Governor's Decree No. 660.1 / K.214 / 2016 concerning the Establishment of the Wehea-Kelay KEE management forum and the Decree of the General Director of KSDAE No. SK.122 / KSDAE / SCT / KSA.4 / 4/2016 concerning the development of a working group to facilitate the formation of institutional management of the Wehea-Kelay landscape. The parties 
voluntarily undertook collaborative management of the Wehea-Kelay landscape that is the Orang Utan corridor.

\section{Challenges in HCV Management on Palm Oil Plantation}

At present, the oil palm plantation sector is in the global concern related to the deforestation issue. The government and environmental stakeholders make efforts to improve the management of oil palm plantation management both through improving regulations and market demands that emphasize business sustainability by taking into account ecological, social and economic aspect. One form of policy to guarantee sustainable oil palm plantations is through a certification system that contains principles and criteria, one of which is to protect the HCV area.

However, the development of $\mathrm{HCV}$ in the concession area of oil palm plantations has not become an awareness for all of the palm oil plantation management units. This paper noted that only the RSPO requires its members to have $\mathrm{HCV}$ area among the existing oil palm plantation certification system, Ministry of Agriculture regulation No. 11/2015 on ISPO has not explicitly mentioned HCV. However, some HCV criteria are scattered in the articles [8].

There are has been identified the challenges of HCV management includes: the legal basis weaknesses that underlie the status of management and protection of $\mathrm{HCV}$ areas, the laws and regulations disharmony that become a disincentive to the management and protection of $\mathrm{HCV}$ areas, trade-offs between conservation of natural resources and economic interests, and the absence of fiscal incentive policies that encourage the management and protection of $\mathrm{HCV}$ areas in implementing $\mathrm{HCV}$ include $[6,8,10]$ :

\section{Disharmony policy:}

a. Regulation of the minister of agriculture No. 11/2015 concerning sustainable palm oil certification system in Indonesia, explained that areas that are not used in accordance with the purpose of granting rights are considered as idle land.

b. Government Regulation No.11 / 2010 concerning Control and Utilization of Abandoned Land, regulates abandoned land which includes land that has been given rights by the state but is not utilized in accordance with the purpose of granting the rights, then the land is considered to be abandoned land which is controlled by the state again. 
c. The law No. 39/2014 concerning plantations, stated that plantation companies must work for the entire area of land rights that can be technically planted with plantations no later than six years after granting land status and if not cultivated, the plantation will be taken over by the state.

d. Inconsistency between standards of voluntary market-based RSPO mechanisms with existing legislation

2. There are worries for plantation companies to set aside their concession area for $\mathrm{HCV}$ which will be considered abandoned land because it is not in according to grant the obtained permit. Besides, $\mathrm{HCV}$, which is managed by a plantation business actor, for the community, is considered to be an unmanaged land and open access so that it can lead to conflict.

3. There is no incentive received by companies that implement HCV so that $\mathrm{HCV}$ management becomes a cost for the company. Furthermore, ISPO certification has not yet been entirely accepted by the global oil palm market $[1,8]$. One effort to encourage business actors to implement $\mathrm{HCV}$ is to provide incentives in the form of regulations governing and protecting $\mathrm{HCV}$ areas and fiscal incentives in the form of tax relief of areas managed as HCV so that $\mathrm{HCV}$ does not become a cost for plantation businesses. 


\section{Incentive Policies to Strengthen the HCV Area Management and Protection}

An incentive policy to encourage the management and protection of $\mathrm{HCV}$ is a requirement to change the motivation and behavior of the parties to encourage the achievement of sustainable palm oil management. Moreover, in Indonesia's policy, the incentive opportunity is to implement the environmental economics instruments as mandated by law no. 32 of 2009 concerning The protection and management of the environment. Further, to provide an appreciation, incentive mechanisms can also be used as a driver for implementing environmental management and protection policies.

Presently, for the parties, the flow funds mechanism that can be used as incentives in the management and protection can be implemented through BLUBPDLH. The Establishment of BLU-Environmental Fund Management Agency is mandated by Government Regulation No. 46 of 2017 concerning Environmental Economic Instruments and Presidential Regulation No. 77 of 2018 concerning Management of Environmental Funds.

There are several policy recommendations of incentive policies that consist of regulatory, fiscal, and institutional incentives as described below:

\section{A. Regulatory Incentives}


To encourage the private sector and other stakeholders businesses to implement HCVs management and protection extensively is expected by creating incentives in the form of laws and regulations reformation that govern the status of HCV areas. The incentive policies are in line with the results of UNEP study (2016) that recommends the necessity of the regulatory incentives to strengthen $\mathrm{HCV}$ protection and management in non-state forest areas (Non-forest area). At this time, the regulation that governs the $\mathrm{HCV}$ area's status in palm oil plantation is a circular letter from the Minister of Agrarian Affairs and Spatial Planning / Head of the National Land Agency (NLA). This circular letter guides the governors, heads of districts, and NLA staff to understand the HCV areas' importance in the non-state forest area and not issued location permits and cultivation permit (HGU) in HCV areas. However, the circular letter deemed ineffective because the circular letter's legal status was lower than the Regulation of the Minister of Agriculture Regulation on ISPO and the Government Regulation on Abandoned Land. Hence, the Environment and Forestry Minister Regulation draft related to Essential Ecosystem Area protection must be issued immediately to clarify the $\mathrm{HCV}$ areas' status since it is considered that this regulation will be strengthening the status of area HCV. It is also necessary to harmonize the relevant regulatory framework so that they do not conflict with each other. Another thing that is needed is strengthening ISPO regulations to encourage the management of $\mathrm{HCV}$ areas and increase the acceptance of ISPO in the international market.

B. Fiscal incentives 
In addition to the need for providing regulation incentives that strengthen HCV protection and management, other incentives can be given to companies that committed to protecting their $\mathrm{HCV}$ areas. The regulation incentives can be in the form of fiscal incentive arrangements such as i) the Building Land Tax (PBB) exemption, increased allocation of fund transfer to the "green" region through intergovernmental fiscal transfer (such as Specific Allocation Fund, Region Incentive Fund, and Village Fund ), ii) allocated Environmental funds, REDD+ funds and partnership funds, iii) application of premium prices and iv) providing the market certainty. Tax exemption needs to be considered because the scope of the area that will be imposed by land and building tax is a whole area, including the productive areas and $\mathrm{HCV}$ area. The land and building tax tariff for the productive area is equal to the non-productive area (HCV area). The tax creates a disincentive for companies that are committed to maintaining $\mathrm{HCV}$ areas in their areas by not converting them to plantation areas. Land and building tax exemption needs to be given so that the tariff will distinguish between the productive and non-productive areas. For example, the tariff of land and building tax for the non-productive area could include behalf of the current tariff. It is expected that this will motivate the private sector to protect their HCV areas in their concession areas.

\section{Institutional incentives}

Another form of incentive that can be formulated is prioritizing palm oil plantation enterprises that manage and protect the HCV area in lending capital to the financial service institutions process. As the Financial Services Authority drives sustainable financial programs, financial services institutions are committed to anticipating the negative impacts of climate change by incorporating risk management principles, preventing, and avoiding negative environmental impacts into the consideration of providing credit. Another proposed incentive is giving a high score to the company in evaluating the company's performance in protecting the environment or in the PROPER program (Company Performance Rating Assessment Program in Environmental Management). 
The potential incentive recipients are $\mathrm{HCV}$ area managers, either single or collaborative managers, consisting of right-holders, permit holders, local government institutions, agencies authorized in the land sector, and / or other managers appointed in law and regulation.

\section{Conclusion}

The discussion on the challenges and policy incentives that are expected to encourage the management and protection of the HCV area could be concluded through four key messages that should be considered by all stakeholders, both government at the central and regional level, private sector, community, and Civil Society Organization. Those are described as follow:

a. Protection of forested and HCV (KEE) areas in oil palm fragmented landscapes play a significant role in biodiversity conservation and reducing deforestation

b. Implementation of KEE and HCV management has yet to be effective due to lack of adoption by business actors, lack of supportive regulatory framework and lack of incentive

c. Effective HCV/KEE policy implementation requires regulatory, fiscal, and institutional incentives $d$. Incentives must be appropriately shared among relevant actors (e.g., managers, local government) through single as well as collaborative schemes

However, this research only includes incentive policies that can promote the implementation of $\mathrm{HCV}$ area management and protection. This study has not explored yet the role of stakeholders, technic of identification and survey of $\mathrm{HCV}$ area, and the impact of HCV area from both ecological and social aspects. Even more the incentive policy is an instrument option that can be taken by the governmen. Based on the findings from this study revealed that there are still obstacles in implementing incentive policies in the management and protection of HCVs in Indonesia. Therefore, further research is needed from various aspects relating to other instruments to support the parties to manage and protect $\mathrm{EEA} / \mathrm{HCV}$.

\section{Acknowledgments}

Our thanks to USAID for facilitating the research and also to all resource person who have supported our research. 


\section{References}

1. Yayasan Tropenbos Indonesia. Konservasi di Luar Kawasan Konservasi (KEE): Pembelajaran dari Kalimantan Barat. Policy Brief. Bogor: Yayasan Tropenbos Indonesia.; 2019.

2. Direktorat Bina Pengelolaan Ekosistem Esensial. Menggapai Ketertarikan Kawasan Eksosistem Esensial [Internet]. ksdae.menlhk.go,id. 2018 [cited 2020 Jul 6]. Available from: http://ksdae.menlhk.go.id/berita/2928/menggapai-ketertarikan-kawasaneksosistem-esensial.html

3. Mulyani A, Agus F. The Need and Availability of Reserved Arable Land Realize Indonesian as the World Food Supplier in 2045. Anal Kebijak Pertan. 2017;15(1):1-17.

4. Santosa Y, Perdana A. The role of High Conservation Value areas in the preservation of mammals diversity in oil palm plantations: a case study in Riau. Sem Nas Masy Biodiv Indon. 2017;3(1):81-7.

5. Nahlunnisa H, Zuhud EAM, Santosa Y. The Diversity of Plant Species in High Conservation Value Area of Oil Palm Plantation in Riau Province. Media Konserv. 2016;21(1):91-8.

6. Tjahjana T. Kebijakan Pengelolaan Kawasan Ekosistem Esensial. Power point persentation. Unpublished. 2019.

7. Nurfatriani F. Reducing deforestation through incentivizing the protection of highconservation areas in fragmented oil palm landscape in Indonesia. Power point persentation. Unpublished. 2019; Asia Pasific Forestry Week Seoul Korea Selatan.

8. Nurjannah S, Amzu E, Sunkar A. Peran Kawasan Bernilai Konservasi Tinggi Bagi Pelestarian Keanekaragaman Hayati Di Perkebunan Kelapa Sawit Provinsi Riau. Risal Kebijak Pertan Dan Lingkung. 2016;3(1):68-77.

9. Jaringan NKT Indonesia. Panduan Pengelolaan dan Pemantauan Nilai Konservasi Tinggi. Jakarta: IFACS-USAID; 2013.

10. Ekawati S, Bahri A, Kartikasari G. Bagaimana Mengimplementasikan Pengelolaan HCV di Sektor Berbasis Lahan: Sebagai Terobosan Kebijakan Pengurangan Emisi di Indonesia. Policy Brief Pus Penelit Dan Pengemb Sos Ekon Kebijak Dan Perubahan Iklim. 2018;12(16).

11. Studi Bersama ISPO-RSPO Sebuah Pencapaian Penting dalam Kerjasama Mewujudkan Minyak Sawit Berkelanjutan di Indonesia [Internet]. rspo.org. 2016 [cited 2020 Jul 17]. Available from: https://rspo.org/news-and-events/news/studi-bersama-isporspo-sebuahpencapaian-penting-dalam-kerjasama-mewujudkan-minyak-sawit-berkelanjutan-diindonesia 
12. Sahide MAK, Fisher M, Nasri, Dharmiasih W, Verheijen B, Maryudi A. Anticipating a New Conservation Bureaucracy? Land and Power in Indonesia's Essential Ecosystem Area Policy. Lan Use Policy 97 2020104789. 2020;

13. Enters T. Incentives as policy instruments: Key concepts and definitions. In: Sanders DW, Huszar PC, Sombatpanit S, Enters T, editors. Incentives in soil conservation. Enfield, N.H: Science Publishers, Inc; 1999. p. 25-40.

14. Giger M, Liniger HP, Critchley W. Use of incentives and profitability of Soil and Water Conservation (SWC). In: Sanders D. et al. 1999: Incentives in soil conservation. New Delhi: Oxford \& IBH Publishing Co. Pvt. Ltd; 1999.

15. Gomm M. Gap Analysis: Methodology, Tool and First Application. Darmstadt (DE): Universitat Hagen; 2009.

16. Pengertian Kebijakan Fiskal dan Tujuannya [Internet]. Available from: https://www.jurnal.id/id/blog/pengertian-kebijakan-fiskal-dan-tujuannya/

17. Thomas E, Powell N, Landers S, R B, Sorrell L. Toward a theory of institutional analysis. MIT Energy Laboratory Report - MIT-EL-78-020. Prepared for the US Department of Energy Under Contract No. EX-76-A-01-2295. 1978.

18. Ostorm E. Formulating the elements of institutional analysis .Paper presented to conference on Institutional Analysis and Development. Washington D.C. May 21-22, 1985. In 1985.

19. Proforest. A technical comparison of the HCV and HCS approaches [Internet]. 2014 [cited $2020 \mathrm{Jul}$ 17]. Available from: https://proforest.net/en/files/hcv-and-hcscompared.pdf

20. Lambin EF, Gibbs HK, Heilmayr R, Carlson KM, Fleck LC, Garrett RD. The role of supply-chain initiatives in reducing deforestation. Nat Clim Change. 2018;8(2):109-16.

21. Nurfatriani F, Ramawati, Kartikasari G, Komarudin H. Optimalisasi Dana Sawit Dan Pengaturan Instrumen Fiskal Penggunaan Lahan Hutan Untuk Perkebunan Dalam Upaya Mengurangi Deforestasi. Working Paper 238. Bogor: CIFOR; 2018.

22. Dewan Kehutanan Nasional (DKN). Kajian Kebijakan Konservasi Sumber Daya Alam Hayati dan Ekosistemnya: Memberikan Kepastian Hukum, Hak Usaha, dan Hak-Hak Masyarakat atas Pemanfaatan Sumberdaya Hutan. Jakarta: Dewan Kehutanan Nasional; 2010 .

23. Simarmata J. Tumpang Tindih Undang-Undang Konservasi Sumber Daya Alam Hayati dan Ekosistemnya. 2018;15(3):185-96.

24. Alika R. Sertifikasi ISPO Capai 5,45 Juta Hektare Hingga Januari 2020 [Internet]. Katadata.co.id. 2020 [cited 2020 Jul 17]. Available from: 
https://katadata.co.id/berita/2020/02/14/sertifikasi-ispo-capai-545-juta-hektare-hinggajanuari-2020

25. Akhmaddhian S. Peran Pemerintah Daerah dalam Mewujudkan Hutan Konservasi Berdasarkan Undang-Undang No. 41 tahun 1999 tentang Kehutanan (Studi di Kabupaten Kuningan). 2013;13(3). 